\title{
Spongivory in the Wakatobi Marine National Park, Southeast Sulawesi, Indonesia ${ }^{1}$
}

\author{
Abigail Powell, ${ }^{2,5}$ Timothy Fones, ${ }^{2}$ David F. Smith, ${ }^{3}$ Famaluddin Fompa,${ }^{4}$ and Fames F. Bell ${ }^{2}$
}

\begin{abstract}
Sponges are functionally important coral reef fauna and there is strong evidence from the Caribbean that predation has important impacts on spongeassemblage dynamics; whether the same is true for Indo-Pacific sponges remains unknown. As a first step toward understanding the potential effects of spongivores on sponge diversity and abundance, we identified sponge predators at nine sites in Wakatobi Marine National Park, Indonesia, and conducted a short-term caging experiment to examine the effects of excluding predators on noncryptic reef sponges at this location. Nudibranchs were the most abundant invertebrate spongivores, although their low densities are likely to limit their influence on sponges. Fish were the most abundant vertebrate spongivores with 16 species from six families observed feeding on sponges. Based on their abundance and our feeding observations, the fish with the greatest potential to influence sponge assemblages in Wakatobi Marine National Park were Zanclus cornutus, Chaetodon kleinii, Pygoplites diacanthus, and Pomacanthus sexstriatus. We did not detect an effect of excluding spongivores on noncryptic reef sponge abundance in our caging experiment, which may be due to these species having evolved chemical defenses against predators. Important areas for further research include the chemical ecology of Indo-Pacific sponges and whether spongivory currently restricts some species to cryptic or nonreef habitats.
\end{abstract}

The ABUNDANCE AND distribution of any species is affected by a number of physical and biological factors operating on a range of spatial and temporal scales (Levin 1992). One of the most important biological factors is predation, which can be broadly defined as any

\footnotetext{
${ }^{1}$ This research was supported by Operation Wallacea who provided funding for travel and field related costs. Abigail Powell was supported by a Commonwealth Scholarship and a Victoria University of Wellington faculty research grant. Manuscript accepted 6 April 2015.

${ }^{2}$ School of Biological Sciences, Victoria University of Wellington, Wellington, New Zealand.

${ }^{3}$ Coral Reef Research Unit, University of Essex, Colchester, United Kingdom.

${ }^{4}$ Research and Development Center on Marine, Coastal and Small Islands, Hasanuddin University, Makassar, Indonesia.

${ }^{5}$ Corresponding author (e-mail: abi.powell@gmail .com).
}

Pacific Science (2015), vol. 69, no. 4:487-508 doi:10.2984/69.4.5

(C) 2015 by University of Hawai'i Press

All rights reserved interaction between two organisms that results in energy flow between them (Paine 1969, Holt 1984, Sih et al. 1985, Chase et al. 2002). The effects of predation can be both direct, by affecting prey densities or indirect by affecting the outcomes of other processes, such as competition (Chase et al. 2002). Most research into the effects of top-down control of benthic organisms on coral reefs has focused on the impacts of herbivorous fish on algal growth (Hughes et al. 2007, Cheal et al. 2010, Lefèvre and Bellwood 2011) and there is less information on the effects of predation on other groups of functionally important benthic reef invertebrates, such as sponges, particularly in the Indo-Pacific.

Given the numerous functional roles of sponges (Bell 2008), changes in sponge abundance could have important effects on the architectural complexity, biodiversity, and productivity of tropical reef systems, with subsequent implications for the social-economic welfare of local people. Therefore, it is important to assess the factors that control sponge distribution and abundance patterns, 
particularly given the possibility that sponges may be more abundant in the future as a consequence of ocean acidification and global warming (Bell et al. 2013). There has been much debate as to the relative importance of biotic and abiotic factors in controlling sponge assemblages (see Wulff 2000, Pawlik et al. 2007, Lesser and Slattery 2013, Pawlik et al. 2013). It was initially thought that predation had little effect on sponges, but research in the Caribbean has shown that its importance had been underestimated (Dunlap and Pawlik 1996, 1998, Pawlik 1998, Wulff 2000, Pawlik et al. 2013, Loh and Pawlik 2014). Observational and experimental work has shown that fish spongivory on coral reefs can affect the distribution of sponges, restricting some species to lagoon or mangrove habitats or to cryptic locations within the reef framework (Wulff 1997a, Pawlik 1998, Hill and Hill 2002). Fish predation has also been shown to reduce the capacity of some sponges to overgrow corals (Hill 1998). Spongivores may also have differential effects on different sponge species, particularly between species that differ in their chemical defenses, which may result in changes to sponge assemblage composition if predation pressure changes (Pawlik et al. 2013). Furthermore, if top-down processes play an important role in controlling sponge populations, then a decline in spongivores (e.g., through overfishing) could lead to an increase in sponges and further reinforce transitions to sponge-dominated systems (see Bell et al. 2013, Loh and Pawlik 2014).

Sponges are preyed on by a number of vertebrate and invertebrate species. The most important vertebrate sponge predators are sea turtles and fish, whereas the most important invertebrate predators are nudibranchs and starfish (Wulff 2006a). Observational and gut content surveys have shown that fish species from a number of families feed on sponges including Pomacanthidae, Monacanthidae, Scaridae, and Ostraciidae (Randall and Hartmann 1968, Wulff 1994, Dunlap and Pawlik 1996, Pawlik 1998). No previous studies have examined the diets and foraging behavior of hawksbill turtles (Eretmochelys imbricata) on Indonesian reefs, but sponges are a major component of the diet of hawksbill turtles in the Caribbean (Meylan 1988, Leon and Bjorndal 2002).

Indonesia is a global center for marine biodiversity with over $51,000 \mathrm{~km}^{2}$ of coral reefs (Allen and Adrim 2003, Allen 2008) and exceptionally high sponge species richness (Van Soest 1989, Bell and Smith 2004, Van Soest et al. 2012). However, to date no studies have examined the impact of spongivory on Indonesian reefs, with most of the information on sponge predation coming from studies based in the Caribbean. There is a pressing need to understand the drivers of sponge abundance and diversity in the Indo-Pacific given the rapid changes that are taking place on reefs in this region (Bruno and Selig 2007, Burke et al. 2011). Indonesian reefs currently face multiple threats (Edinger et al. 1998, PetSoede et al. 1999, Todd et al. 2010), which are likely to have major impacts on reef organisms including spongivores. For example, it is estimated that the number of nesting hawksbill turtles in Indonesia has declined by $80 \%$ over the past 100 years due to exploitation (Meylan and Donnelly 1999). Fishing has the potential to influence sponge abundance positively by reducing spongivorous fish abundance, but it could also have negative effects by increasing algal competition for space through the removal of herbivorous fishes (Hughes et al. 2007). The net effect is likely dependent on the relative abundance of different fish functional guilds and the type of fisheries techniques used.

A prerequisite to determining the role of predation in controlling sponge distributions and abundance on Indo-Pacific reefs is the identification of spongivores and the extent to which different species prey upon sponges under any given set of environmental conditions. To date no studies have focused specifically on the diet of spongivorous fish in Indonesia, but a number of surveys from around the Pacific provide an insight into which species are likely to feed on sponges. Wulff (1997b) examined the role of predation on sponge assemblages on either side of the isthmus of Panama and found that cryptic $\mathrm{Pa}$ cific sponges were rapidly consumed when exposed to sponge predators including an 
angelfish (Holocanthus passer), the Moorish idol (Zanclus cornutus), a triggerfish (Sufflamen verres), a pufferfish (Canthigaster punctatissima), and a parrotfish (Scarus ghobban). However, sponges that lived exposed or semi-exposed on the reef were not consumed in $50 \%$ of trials when presented to the spongivore, Arothron hispidus. Another study from the eastern Pacific concluded that sponge predation has little effect on the distribution and abundance of sponges on the Mexican Pacific Coast (Padilla Verdin et al. 2010). Studies of fish gut contents were conducted by Hiatt and Strasburg (1960), Hobson (1974), and Sano et al. (1984) who examined the gut contents of fishes from the Marshall Islands, Hawai' $i$, and Japan, respectively. These studies have highlighted certain groups and species that feed on sponges in the Pacific. The largest consumers of sponge appear to be in the families Zanclidae, Tetraodontidae, Ostraciontidae, Pomacanthidae, Siganidae, Monacanthidae and Pomacentridae. However, there appears to be considerable variation in the extent to which Pacific reef fish species in the same family feed on sponges. For example, Sano et al. (1984) determined that sponges accounted for $72 \%$ of the gut contents of the rabbitfish, Siganus chrysospilos, but $<1 \%$ in two of the other rabbitfish species examined. There also appears to be considerable variation in feeding habits between locations. For example, Chaetodon kleinii fed on zooplankton in Hawai'i (Hobson 1974) but feeds on benthic invertebrates in other locations including the Ryukyu Islands in Japan (Sano 1989) and East Kalimantan in Indonesia (Nagelkerken et al. 2009). The plasticity of fish feeding behavior means that there is a need for more comprehensive studies to identify those species that contribute to spongivory in Indonesia and to determine whether the extent of spongivory is environmentally regulated or a fixed species trait.

The aim of this study was to identify the spongivores present in the Wakatobi Marine National Park (WMNP), Southeast Sulawesi, Indonesia, and to assess their potential impact through observations of feeding behavior and an exclusion experiment. Our specific objectives were (1) to identify spongivorous fish using timed in situ observations of fish feeding behavior, (2) to estimate the importance of invertebrate spongivores by recording signs of spongivory and by examining associations between invertebrates and the substrates where they were found, and (3) to use a short-term caging experiment at two sites to examine the effects of excluding fish on noncryptic reef sponges in the WMNP.

\section{MATERIALS AND METHODS}

\section{Study Sites}

Fish and invertebrate (Nudibranchia and Asteroidea) abundance and diversity surveys were carried out on reef slopes at nine sites in the WMNP in Southeast Sulawesi, Indonesia. The WMNP was gazetted in 1996 and is the third largest marine national park in Indonesia (Clifton and Unsworth 2010); this area was also designated a Biosphere Reserve by the United Nations Educational, Scientific, and Cultural Organization in 2012. It is located in the coral triangle and supports highly biodiverse marine communities, but is also inhabited by over 90,000 people, and local communities are highly dependent on reef resources for food and income (Cullen-Unsworth et al. 2011). Declines in hard coral cover have been documented in the park since 2002 (McMellor and Smith 2010) and there is also evidence that a number of nearshore fisheries are currently being exploited at unsustainable levels (Exton 2010). Sites were located on the fringing reefs of Kaledupa and Hoga Islands (see Figure 1). These sites were selected as they encompass a range of environmental and biological conditions (Powell et al. 2014). It is important to note that this study of spongivory was carried out in a location where fish assemblages and potential spongivore abundances have likely been altered by fishing. Site characteristics are summarized in Table 1. Surveys were carried out between 0700 and 1700 from June-August 2009.

\section{Fish Surveys and Feeding Observations}

Fish surveys were carried out by divers using scuba equipment on reef slopes at a depth of approximately $10 \mathrm{~m}$ (between 8 and $12 \mathrm{~m}$ 


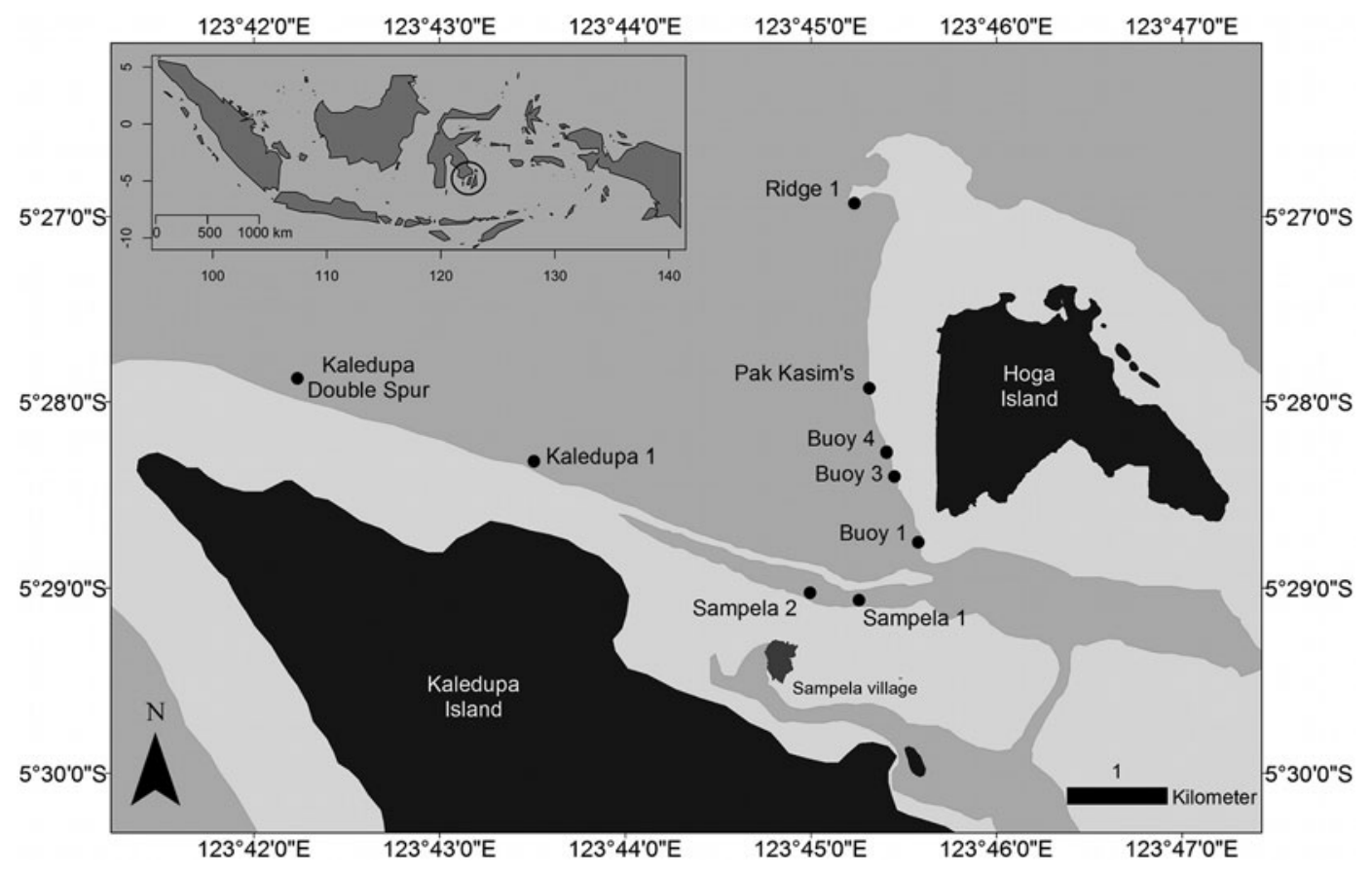

FIGURE 1. Map showing the nine study sites off the islands of Hoga and Kaledupa in the WMNP and the location of Sampela village. Inset is a map of Indonesia with the location of Southeast Sulawesi circled.

dependent on tide) at the nine study sites. Three $50 \mathrm{~m}$ long $\times 5 \mathrm{~m}$ wide belt transects were used to assess fish communities at each site. A 10-min acclimation period was allowed to elapse prior to starting fish counts. Survey time was restricted to $25 \mathrm{~min}$ per transect. Observations of fish feeding behavior were carried out at two sites, Sampela 1 and Buoy 3. These sites were selected in order to maximize the number of different fish species that could be observed as they are characterized by different reef topography, coral cover, and environmental conditions (Table 1). Fish observations were carried out within three rectangular $150 \mathrm{~m}^{2}$ plots $(30 \mathrm{~m}$ long $\times 5 \mathrm{~m}$ wide) marked out with flagging tape on the reef slope at each site at a depth between $7.5 \mathrm{~m}$ (top of the plot) and $12.5 \mathrm{~m}$ (bottom of the plot). The habitat within the plots was surveyed with photoquadrats $(10 \times$ $1 \mathrm{~m}^{2}$ photoquadrats analyzed per plot) so that the number of bites taken by fish on sponges could be compared with the proportion of sponge in the environment. The locations of the photoquadrats within the plots were randomly selected prior to the survey. To assist with subsequent image analysis, the photoquadrats were subdivided into nine sections and close-up images were taken of these squares in addition to the photograph of the overall quadrat. Images were analyzed using the program Coral Point Count with Excel extensions (Kohler and Gill 2006). Twenty points were randomly overlaid on each quadrat image and the substrate type under each point was recorded. Substrate types included were sponge, hard coral, soft coral, coralline algae, other algae, dead coral (structure of coral skeleton still visible), dead coral covered in algae, rock, rubble, sand, and other (ascidians, anemones, and gorgonians). The closeup images were used as a reference to aid with identification. Fish feeding observations within the sample plot were carried out by following individual fish for $3 \mathrm{~min}$. Pilot trials showed that this was the optimum time that fish naturally stayed within the study area. Every bite taken by fish and the food item 
TABLE 1

Description of Study Site Characteristics

\begin{tabular}{|c|c|c|c|c|}
\hline Site & $\begin{array}{l}\text { General Description of } \\
\text { Reef Slopes }\end{array}$ & Fishing Pressure & Sedimentation & $\begin{array}{c}\text { Mean Hard Coral } \\
\text { Cover (\%) }\end{array}$ \\
\hline $\begin{array}{l}\text { Sampela } 1 \\
5^{\circ} 29^{\prime} 4.47^{\prime \prime} \mathrm{S} 123^{\circ} \\
45^{\prime} 13.78^{\prime \prime} \mathrm{E}\end{array}$ & $\begin{array}{l}\text { Slope aspect: } 40^{\circ}-50^{\circ} \\
\text { This site is adjacent to } \\
\text { the Bajo village of } \\
\text { Sampela, which is built } \\
\text { on the reef flat. Gentle } \\
\text { slope with low coral } \\
\text { cover ( } 10 \%-20 \%) \text { and } \\
\text { rubble slips. }\end{array}$ & $\begin{array}{l}\text { The close proximity to } \\
\text { Sampela village means } \\
\text { that this site experi- } \\
\text { ences relatively high } \\
\text { levels of fishing } \\
\text { pressure. }\end{array}$ & High & $10-20$ \\
\hline $\begin{array}{l}\text { Sampela } 2 \\
5^{\circ} 28^{\prime} 59.76^{\prime \prime} \mathrm{S} 123^{\circ} \\
44^{\prime} 54.75^{\prime \prime} \mathrm{E}\end{array}$ & $\begin{array}{l}\text { Slope aspect: } 40^{\circ}-50^{\circ} \\
\text { This site is situated } \\
300 \mathrm{~m} \text { to the west of } \\
\text { Sampela } 1 \text { and the } \\
\text { topography of the reef } \\
\text { slope is similar but has } \\
\text { slightly lower coral } \\
\text { cover }(0 \%-10 \%) \text {. }\end{array}$ & $\begin{array}{l}\text { Like Sampela 1, this } \\
\text { site experiences } \\
\text { relatively high levels of } \\
\text { fishing pressure. }\end{array}$ & High & $0-10$ \\
\hline $\begin{array}{l}\text { Kaledupa } \\
5^{\circ} 28^{\prime} 19.18^{\prime \prime} \mathrm{S} 123^{\circ} \\
43^{\prime} 32.64^{\prime \prime} \mathrm{E}\end{array}$ & $\begin{array}{l}\text { Slope aspect: } 50^{\circ}-70^{\circ} \\
\text { The reef crest is } \\
\text { located } 300 \mathrm{~m} \text { offshore } \\
\text { adjacent to seagrass } \\
\text { beds and areas of } \\
\text { mangrove. Steep slope } \\
\text { with high soft coral } \\
\text { cover descending to } \\
\text { over } 50 \mathrm{~m} \text { to sloping } \\
\text { sandy bottom. Coral } \\
\text { cover is between } 10 \% \\
\text { and } 20 \% \text {. }\end{array}$ & $\begin{array}{l}\text { There is evidence of } \\
\text { past bomb fishing. } \\
\text { There are also some } \\
\text { fish fences on the reef } \\
\text { flats. }\end{array}$ & Moderate & $10-20$ \\
\hline $\begin{array}{l}\text { Kaledupa Double } \\
\text { Spur } \\
5^{\circ} 27^{\prime} 56.16^{\prime \prime} \mathrm{S} 123^{\circ} \\
42^{\prime} 14.29^{\prime \prime} \mathrm{E}\end{array}$ & $\begin{array}{l}\text { Slope aspect: } 50^{\circ}-90^{\circ} \\
\text { This site is located at } \\
\text { the northern tip of } \\
\text { Kaledupa Island. It is } \\
\text { characterized by steep } \\
\text { walls with large } \\
\text { gorgonians and } \\
\text { sponges interspersed } \\
\text { with sandy slopes. } \\
\text { Descends to depths of } \\
\text { over } 70 \mathrm{~m} \text {. }\end{array}$ & $\begin{array}{l}\text { Deeper site and greater } \\
\text { distance from Sampela } \\
\text { village and Abeua } \\
\text { means fewer fish } \\
\text { fences. Low levels of } \\
\text { hook and line fishing. } \\
\text { Some evidence of } \\
\text { bomb fishing. }\end{array}$ & Low & $30-40$ \\
\hline $\begin{array}{l}\text { Buoy } 1 \\
5^{\circ} 28^{\prime} 48.22^{\prime \prime} \mathrm{S} 123^{\circ} \\
45^{\prime} 35.01^{\prime \prime} \mathrm{E}\end{array}$ & $\begin{array}{l}\text { Slope aspect: } 70^{\circ}-90^{\circ} \\
\text { This site is situated at } \\
\text { the southwestern tip of } \\
\text { Hoga Island in the } \\
\text { channel between Hoga } \\
\text { and Kaledupa Islands. } \\
\text { Steep wall character- } \\
\text { ized by caves and } \\
\text { overhangs that turns } \\
\text { into a sandy slope at } \\
\text { approximately } 40 \mathrm{~m} \text {. }\end{array}$ & $\begin{array}{l}\text { Hook and line fishing } \\
\text { occurs on the wall. }\end{array}$ & Moderate & $20-30$ \\
\hline
\end{tabular}


TABLE 1 (continued)

\begin{tabular}{|c|c|c|c|c|}
\hline Site & $\begin{array}{l}\text { General Description of } \\
\text { Reef Slopes }\end{array}$ & Fishing Pressure & Sedimentation & $\begin{array}{c}\text { Mean Hard Coral } \\
\text { Cover }(\%)\end{array}$ \\
\hline $\begin{array}{l}\text { Buoy } 3 \\
5^{\circ} 28^{\prime} 29.57^{\prime \prime} \mathrm{S} 123^{\circ} \\
45^{\prime} 29.40^{\prime \prime} \mathrm{E}\end{array}$ & $\begin{array}{l}\text { Slope aspect: } 70^{\circ}-90^{\circ} \\
\text { The reef crest is } \\
\text { located approximately } \\
150 \mathrm{~m} \text { offshore adjacent } \\
\text { to seagrass beds. Steep } \\
\text { wall characterized by } \\
\text { caves and overhangs } \\
\text { with high cover of } \\
\text { encrusting hard corals } \\
(30 \%-40 \%) \text {. Descends } \\
\text { to sandy flat at } \\
\text { approximately } 30 \mathrm{~m} \text {. }\end{array}$ & $\begin{array}{l}\text { This site used to be a } \\
\text { no take area but was } \\
\text { re-opened to fishing in } \\
2007 \text {. Hook and line } \\
\text { fishing occurs on the } \\
\text { wall. }\end{array}$ & Moderate & $30-40$ \\
\hline $\begin{array}{l}\text { Buoy } 4 \\
5^{\circ} 28^{\prime} 20.42^{\prime \prime} \mathrm{S} 123^{\circ} \\
45^{\prime} 26.48^{\prime \prime} \mathrm{E}\end{array}$ & $\begin{array}{l}\text { Slope aspect: } 70^{\circ}-90^{\circ} \\
\text { This site is situated } \\
200 \mathrm{~m} \text { north of Buoy } 3 \\
\text { and has a similar } \\
\text { topography with a } \\
\text { steep wall characterized } \\
\text { by caves and overhangs. } \\
\text { Mean hard coral cover } \\
\text { is } 40 \%-50 \% \text {. Descends } \\
\text { to sandy flat at } \\
\text { approximately } 30 \mathrm{~m} \text {. }\end{array}$ & $\begin{array}{l}\text { Hook and line fishing } \\
\text { occurs on the wall. }\end{array}$ & Moderate & $40-50$ \\
\hline $\begin{array}{l}\text { Pak Kasim's } \\
5^{\circ} 28^{\prime} 1.30^{\prime \prime} \mathrm{S} 123^{\circ} \\
45^{\prime} 20.49^{\prime \prime} \mathrm{E}\end{array}$ & $\begin{array}{l}\text { Slope aspect: } 50^{\circ}-70^{\circ} \\
\text { The site is located } \\
400 \mathrm{~m} \text { north of Buoy } 4 \\
\text { on the same fringing } \\
\text { reef. The slope aspect } \\
\text { is slightly less steep } \\
\text { and is characterized by } \\
\text { high hard coral cover } \\
(40 \%-50 \%) \text {. }\end{array}$ & $\begin{array}{l}\text { This site experiences } \\
\text { relatively low levels of } \\
\text { fishing pressure }\end{array}$ & Low & $40-50$ \\
\hline $\begin{array}{l}\text { Ridge } 1 \\
5^{\circ} 27^{\prime} 10.76^{\prime \prime} \mathrm{S} 123^{\circ} \\
45^{\prime} 8.82^{\prime \prime} \mathrm{E}\end{array}$ & $\begin{array}{l}\text { Slope aspect: } 60^{\circ}-80^{\circ} \\
\text { Ridge situated } 1 \mathrm{~km} \\
\text { offshore to the west of } \\
\text { Hoga Island running } \\
\text { north to south. Surveys } \\
\text { were carried out on the } \\
\text { outer slope. Steep slope } \\
\text { dropping to over } \\
100 \mathrm{~m} \text {. }\end{array}$ & $\begin{array}{l}\text { Relatively low fishing } \\
\text { pressure }\end{array}$ & Low & $30-40$ \\
\hline
\end{tabular}

that was fed on was recorded. Food categories recorded included sponge, hard coral, soft coral, coralline algae, other algae, dead coral (structure of coral skeleton still visible), dead coral covered in algae, rock, rubble, sand and other (ascidians, anemones, and gorgonians). While in most cases it was not possible to determine the identity of sponges being fed on, where possible this information was also recorded. The proportion of each food item available at each site was determined from the photoquadrats. At least three individuals of each fish species were observed. Observations were limited to adult fishes that were identified on the basis of size, coloration, and other morphological characteristics. 


\section{Invertebrate Surveys}

Surveys of Nudibranchia and Asteroidea were carried out on reef slopes at a depth of approximately $10 \mathrm{~m}$ at the nine study sites. All nudibranchs and starfish present $2.5 \mathrm{~m}$ on each side of a $30 \mathrm{~m}$ transect were identified and recorded. Three transects were completed at each study site and surveys were limited to 25 min per transect in order to avoid differential search effort among replicates. The substrate that the nudibranchs and starfish were on and any signs of feeding behavior, such as the presence of feeding scars on the surface of sponges, was also recorded. Benthic habitat characteristics at the study sites were also surveyed using photoquadrats.

\section{Caging Experiment}

An exclusion experiment was set up at four sites within two reef systems in the WMNP (two replicate sites within each reef system). Two sites, Sampela 1 and Sampela 2, were located on the fringing reef that surrounds Kaledupa Island. These sites were considered representative of a degraded reef system with a mean percentage hard coral cover of approximately $10 \%$ and high levels of sedimentation (Salinas-de-León et al. 2011). The reef slope at these sites descended at approximately $45^{\circ}$ to sand flats at $11-14 \mathrm{~m}$ depth. The two other sites, Buoy 3 and Buoy 4, were located on the fringing reef on the western side of Hoga Island. These had relatively high levels of hard coral cover (approximately 40\%) and low sedimentation rates and were characterized by walls, overhangs, and caves (Salinas-de-León et al. 2011).

Twelve $25 \times 15 \mathrm{~cm}$ vertical plots were haphazardly selected at each site at a depth of $10 \mathrm{~m}$. Each plot was tagged and randomly assigned one of three different treatments: full cage, partial cage, or no-cage control. The full cages were made from plastic $1.5 \times 1.5 \mathrm{~cm}$ mesh. The size of the mesh was selected to be small enough to exclude most adult spongivorous fish. The no-cage plots were used as controls against which to measure the effects of excluding predators. In order to separate the effects of predator exclusion from caging artifacts caused by the physical presence of the cage, partial cages that had the top removed were also deployed to mimic the presence of the cage while still allowing predation to occur. Stainless steel metal fencing staples were used to anchor the full and partial cages to the substrate. The cages were attached to the staples with cable ties so that they could be easily removed for cleaning. Four replicates of each treatment were established at each site. The abundances (number of individual sponges) of each sponge species were recorded along with total sponge abundance within all the study plots at the beginning of the experiment in March 2009 and again after 6 months in August 2009 to assess for any caging effects.

\section{Data Analysis}

Statistical analyses of spongivore diversity and abundance were carried out using PRIMER-E (Plymouth Routines in Multivariate Ecological Research) ver. 6 with PERMANOVA+ add-on (Anderson et al. 2008). A univariate permutational multivariate analysis of variance (PERMANOVA) with site as a fixed factor with nine levels was used to test the null hypothesis that there was no difference in fish abundance between the study sites. The same PERMANOVA design was also used to test the null hypothesis that there was no difference in the multivariate fish assemblages between the study sites. Unconstrained multidimensional scaling (MDS) and constrained canonical analysis of principal coordinates (CAP) were used to visualize differences in the fish assemblages between the study sites. Vectors representing Pearson's correlations with the resulting CAP axes were used to identify the species that characterized the differences in multivariate fish assemblages between sites. An unconstrained MDS plot was also used to visualize differences in the food items fed on by fish in different families.

Ivlev's (1961) electivity index was used to test whether fish fed more often on sponges than would be expected given the proportion of sponge in the environment: 


$$
E=\frac{r i-p i}{r i+p i}
$$

where $E$ is the electivity measure, $r i$ is the percentage of bites taken of sponge, and $p i$ is the percentage cover of sponge (sponge \% cover) in the environment. The value of the index ranges from -1 to +1 where negative values indicate avoidance of sponges and positive values represent active selection of sponges. To account for the variability associated with our measurement of diet selectivity, we calculated a $95 \%$ confidence interval (CI) of Ivlev's electivity index for each species based on a bootstrapping procedure in $\mathrm{R}$ (ver. 3.0.2; R Core Team 2013). To account for the uncertainty in the proportion of bites taken on sponges, we sampled $N$ (where $N$ was the total number of bites observed for that species) items, with replacement, from the observed list of numbers of bites on different substrates for that species. From this random sample, we calculated the simulated proportion of bites that occurred on sponges. Similarly, to account for the uncertainty of sponge availability at each site, we sampled (with replacement) 30 items at random from the list of observations of sponge \% cover, with each recorded observation equal to the sponge \% cover within 1 of the 30 quadrats deployed at each site. From this random sample, we calculated the mean proportion of sponge availability in the environment. Based on the resampled proportion of bites taken on sponge and the resampled proportion of sponge in the environment, we calculated Ivlev's electivity index, $E$. This procedure was repeated 10,000 times to build up a distribution of possible values for $E$ for each species, and the 2.5th and 97.5th percentiles of this distribution are taken to represent the $95 \%$ CI. In addition to fish, sea turtles are potentially important vertebrate spongivores, but due to a lack of data (one hawksbill turtle was observed throughout the surveys) their potential impact on sponges in this area could not be assessed.

\section{Nudibranch Data}

A univariate PERMANOVA with site as a fixed factor with nine levels was used to test the null hypothesis that there was no difference in nudibranch abundance between study sites. The same PERMANOVA design was also used on the multivariate nudibranch assemblage data to test the null hypothesis that there was no difference in nudibranch assemblages among the study sites. MDS and CAP plots were used to visualize differences in nudibranch assemblages among sites. Ivlev's electivity index was used to test whether nudibranchs were found more often on sponges than would be expected given the proportion of sponge in the environment where $E$ is the electivity measure, $r i$ is the percentage of nudibranchs observed on sponge, and $p i$ is the percentage cover of sponge in the environment. Similar to the analyses for fish, a bootstrapping procedure was used to obtain the 95\% CI for Ivlev's electivity index for each nudibranch species. This analysis was not carried out for species where fewer than three individuals were observed.

\section{Caging Data}

Sponge abundance in the caged plots was measured in March and August and the change in sponge abundance in each plot was calculated as the final (August) minus the initial (March) sponge abundance. The resulting change in sponge abundance was the response variable in the following statistical analyses. Observations from replicate sites were pooled to reef level in order to increase our statistical power. Sampela 1 and Sampela 2 were combined from the degraded reef and Buoy 3 and Buoy 4 were combined on the higher quality reef. The assumptions of ANOVA (normality and homogeneity of variance) were tested using Shapiro-Wilk's tests for normality (Shapiro and Wilk 1965) and Levene's test for homogeneity of variance. These tests revealed that the null hypothesis of normally distributed data could only be rejected (at the $5 \%$ significance level) for one treatment group: partial cages at Sampela. However, all other groups were adequately described by normal distributions, and so all further analyses were performed assuming normally distributed data. Levene's tests showed that variances were significantly different between Hoga and 
Sampela but were not significantly different within sites. Consequently, further analyses were performed separately for Sampela and Hoga. A one-factor ANOVA with fixed effect of treatment (three levels: no cage, cage, partial cage) was used to test for differences between experimental treatments.

\section{Power Analysis on Caging Data}

In cases where no significant difference is detected between caged and noncaged plots, it can be difficult to conclude whether the lack of a statistically significant effect is due to a small actual effect or whether the experimental design was inadequate for detecting the difference. In these situations, retrospective power analysis can be used to assess the capacity of a study to detect a biologically meaningful effect (Thomas 1997) and to place bounds on the size of the effect (given that there is one) that the study would have been able to detect. Therefore, we conducted a retrospective power analysis to estimate the power of the experimental design to detect predefined effect sizes. The power analyses were carried out using the program $\mathrm{G}^{*}$ power ver. 3.1 (Faul et al. 2007). Power analyses were carried out to identify the power of an ANOVA analysis to reject the null hypothesis (at the 5\% significance level) of no difference in change values between experimental treatments. Due to the lack of information in the literature regarding the size of predation effects on sponges, power was calculated for a range of effect sizes. Standard effect sizes were calculated using the formula for Cohen's $d$, which is the difference between the treatment means divided by the standard deviation of either group (Cohen 1977):

$$
d=\frac{m_{\max }-m_{\min }}{\sigma}
$$

We set $m_{\text {min }}$ to zero, representing no change in sponge abundance in the uncaged plot treatment. To examine the relationship between the power of the experiment and effect size, a range of $m_{\max }$ values, representative of percentage increases in mean sponge abundance of $10 \%-100 \%$ relative to initial sponge abundance in caged plots, were used (this represents a maximum of a doubling of sponge abundance in caged plots). The standard deviation of sponge abundance in caged plots in March was used to represent $\sigma$. To calculate power, $d$ values were converted to a primary effect size index $f$ (see table 8.2.1 in Cohen [1977]) and entered into $G^{*}$ power 3.1 with a total sample size of $n=16$ with two treatment groups as per the experimental design.

\section{Caging Effects on Sponge Assemblage Structure}

An unconstrained nonmetric MDS plot was used to graphically represent differences in the sponge assemblages at Sampela and Hoga scaled to two dimensions. A three-factor PERMANOVA was used to determine whether caging treatment had an effect on sponge assemblages over time at the study sites. The PERMANOVA incorporated the following factors: (1) site (fixed factor with two levels), (2) treatment (fixed factor with three levels), and (3) time (fixed factor with two levels).

\section{RESULTS}

\section{Fish Surveys and Feeding Observations}

In total, 188 species of fish representing 30 families were recorded on the 27 reef slope transects with a mean number of fish of 385 $(\mathrm{SD}=141)$ per $250 \mathrm{~m}^{2}$. The feeding behavior of 45 species in 12 families was observed at Sampela and Buoy 3. The mean number of bites that each species took on each food item is summarized in Table 2. Some food items, such as dead coral covered in algae and coralline algae, were fed on by a large proportion of the species observed ( $>50 \%)$, whereas others were only fed on by a few species such as soft coral (nine species). In total, 16 species in nine families took bites from sponges (Table 2 ). Although in most cases it was not possible to identify the sponges being fed on during the feeding observations, Table 3 contains additional information for a number of sponges that could be identified to genus or species level. Xestospongia testudinaria was fed on the most out of the sponges that could be recognized followed by an unidentified species, Spheciospongia sp. in the family Clionaidae. Of 


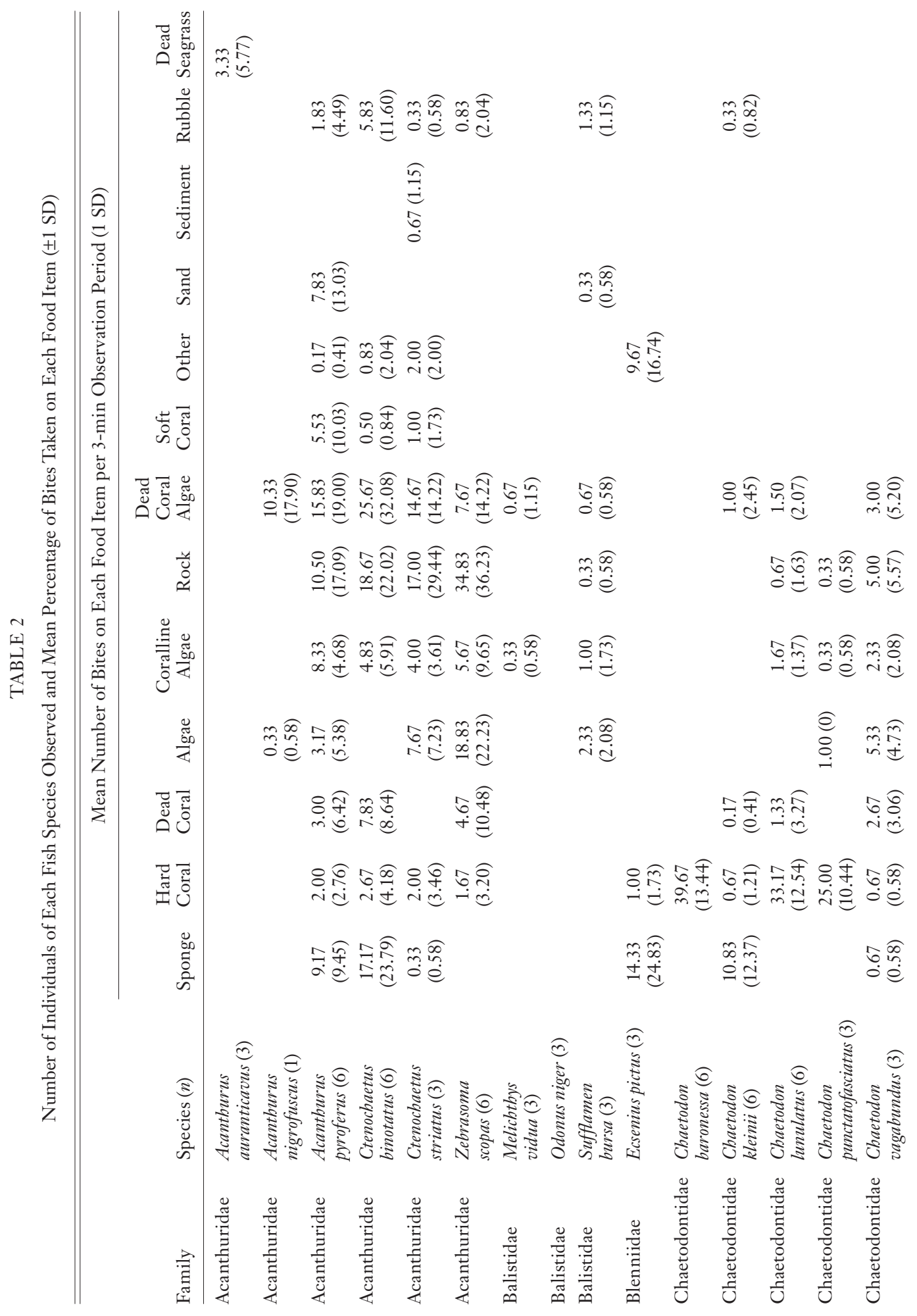


당

œ̊

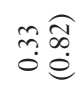

min
3.

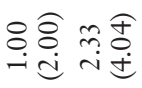

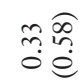

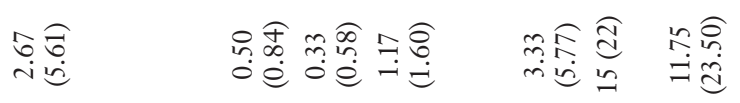

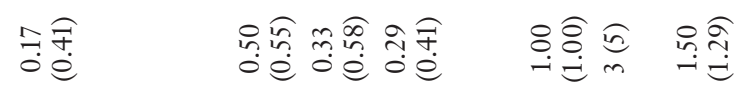

$\stackrel{\substack{0 \\ 0}}{=}$

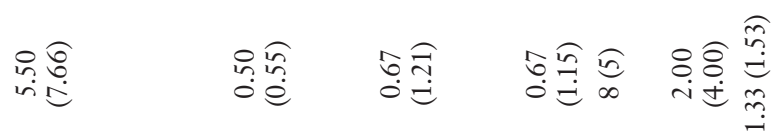

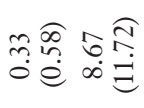

诲

些

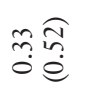

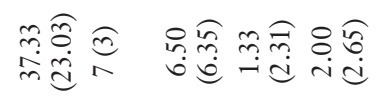

mad

ind

웡

高

呑

으릉

롤 $\quad$ 월

고용ㅇㅇ

$m i \infty$

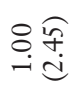

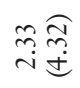

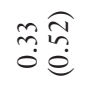

mâิ

늘

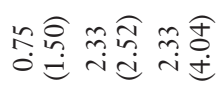

욜ㄹㄹ

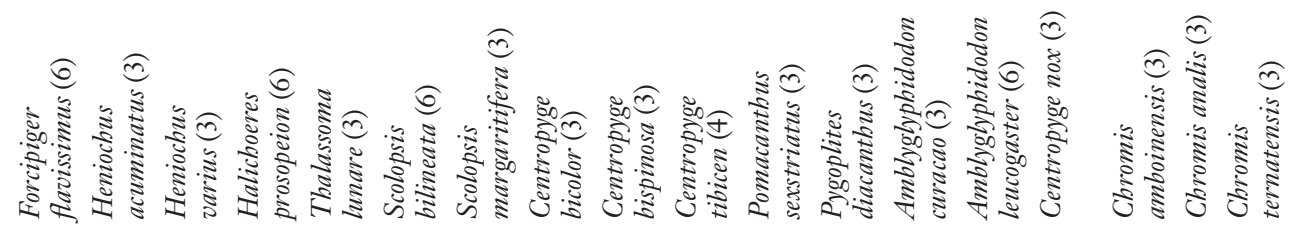

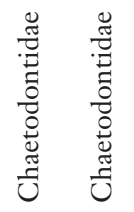

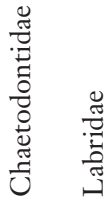
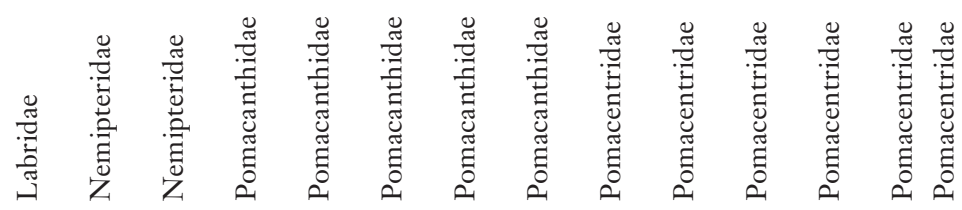


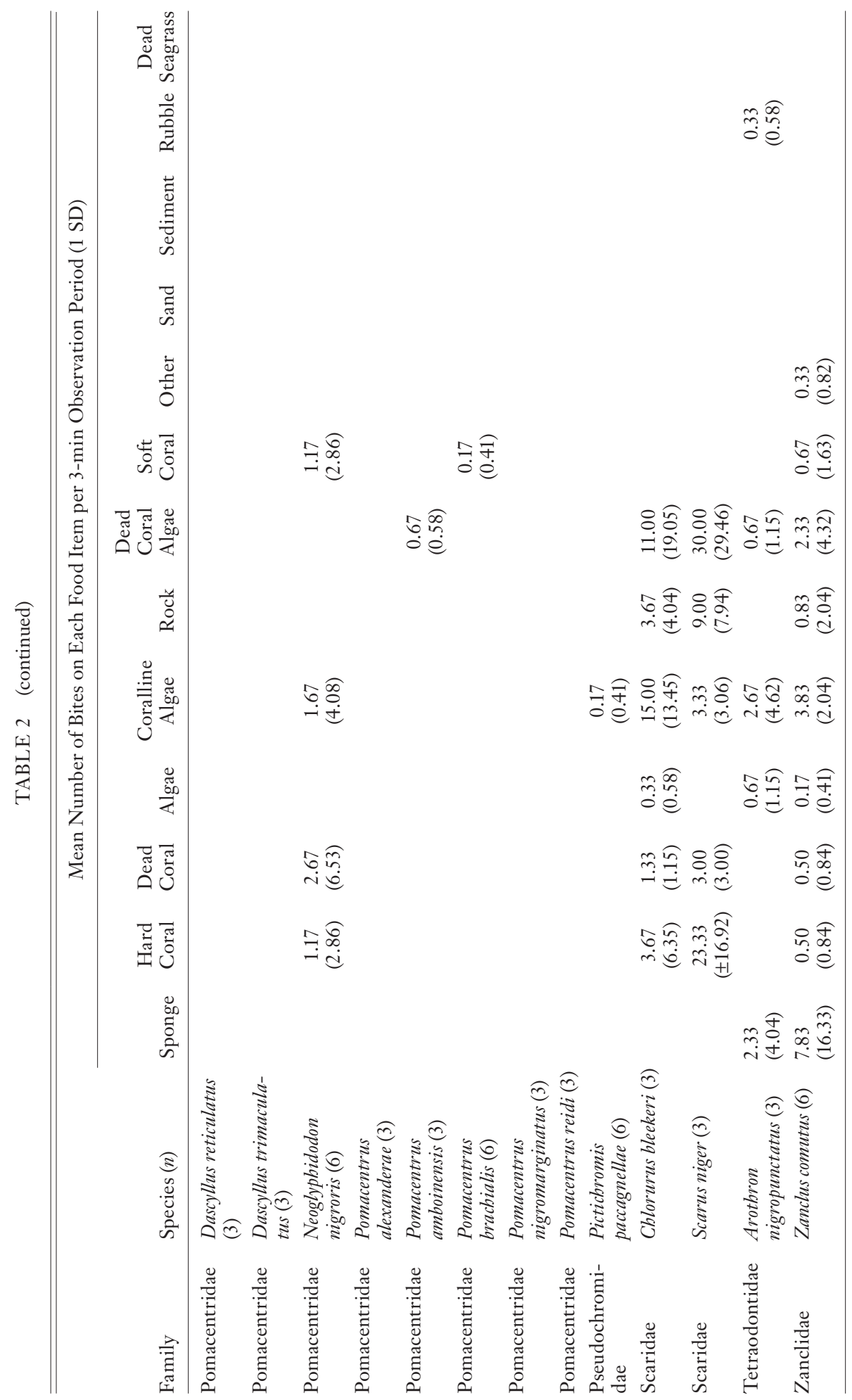


TABLE 3

Fish Species Observed Feeding on Sponges that Could Be Identified at Hoga and Sampela

\begin{tabular}{|c|c|c|c|c|}
\hline Sponge & Fish Predator & Individual & Site & $\begin{array}{c}\text { Number of Bites } \\
\text { in a 3-min } \\
\text { Observation Period }\end{array}$ \\
\hline \multirow[t]{2}{*}{ Hyrtios erectus (Keller, 1889) } & Pygoplites diacanthus & 1 & Sampela & 7 \\
\hline & Scolopsis bilineata & 1 & Sampela & 1 \\
\hline Faspis splendens (de Laubenfels, 1954) & Pomacanthus sexstriatus & 1 & Hoga & 1 \\
\hline \multirow{4}{*}{ Lamellodysidea berbacea (Keller, 1889) } & Acanthurus pyroferus & 1 & Sampela & 2 \\
\hline & & 2 & Sampela & 1 \\
\hline & Ctenochaetus binotatus & 1 & Sampela & 9 \\
\hline & Ctenochaetus striatus & 1 & Sampela & 1 \\
\hline \multirow{2}{*}{$\begin{array}{l}\text { Liosina cf. granularis (Kelly Borges and } \\
\quad \text { Bergquist, 1988) }\end{array}$} & Centropyge tibicen & 1 & Sampela & 3 \\
\hline & Ctenochaetus binotatus & 1 & Sampela & 4 \\
\hline \multirow{7}{*}{ Spheciospongia sp. } & Acanthurus pyroferus & 1 & Hoga & 19 \\
\hline & & 2 & Hoga & 12 \\
\hline & Ctenochaetus binotatus & 1 & Hoga & 30 \\
\hline & & 2 & Hoga & 32 \\
\hline & Forcipiger flavissimus & 1 & Hoga & 11 \\
\hline & & 2 & Hoga & 2 \\
\hline & Scolopsis bilineata & 1 & Hoga & 1 \\
\hline \multirow[t]{2}{*}{ Theonella swinhoei (Gray, 1868) } & Ctenochaetus binotatus & 1 & Hoga & 28 \\
\hline & Ecsenius pictus & 1 & Hoga & 43 \\
\hline \multirow[t]{7}{*}{ Xestospongia testudinaria (Lamarck, 1815) } & Acantburus pyroferus & 1 & Sampela & 21 \\
\hline & Chaetodon kleinii & 1 & Hoga & 18 \\
\hline & & 2 & Sampela & 28 \\
\hline & & 3 & Sampela & 19 \\
\hline & Chaetodon vagabundus & 1 & Hoga & 1 \\
\hline & Zanclus cornutus & 1 & Sampela & 4 \\
\hline & & 2 & Sampela & 41 \\
\hline
\end{tabular}

the species observed taking bites of sponges, nine species (Acantburus pyroferus, Ctenocbaetus binotatus, Ecsenius pictus, Chaetodon kleinii, Forcipiger flavissimus, Pomacanthus sexstriatus, Pygoplites diacanthus, Arotbron nigropunctactus, and $Z$. cornutus) selectively fed on sponges at either one or both of the study sites $(E>0.7$ and CIs that did not cross zero) (Table 4).

The highest mean number of bites on sponge, $17(\mathrm{SD}=24)$ per 3 -min observation period, was taken by a surgeonfish, Ctenochaetus binotatus. Of the two other surgeonfish observed, Acanthurus pyroferus appeared to feed selectively on sponges, particularly at Hoga $(E=0.85)$ but Ctenochaetus striatus took only one bite of sponge and seemed to avoid sponges (at Sampela, $E=-0.78$ ). The species that took the second highest mean number of bites was the blenny, Ecsenius pictus, with a mean of $14(\mathrm{SD}=25)$ per 3-min observation period. Of the three individuals observed of this species, the first fed solely on X. testudinaria, the second took bites of an ascidian, and the last individual was not observed feeding. Three species of butterflyfish were observed feeding on sponges. Chaetodon kleinii took on average $11(\mathrm{SD}=12)$ bites of sponge per 3-min observation period. This species fed selectively on sponges at Sampela $(E>0.8)$ and at Hoga $(E>0.9)$ and overall a large proportion of the total bites taken by this species were taken on sponge (82\%). Forcipiger flavissimus appeared to selectively feed on sponges at Hoga $(E=0.84)$ but not at Sampela $(E=-0.15)$; however, the number of bites observed at Sampela was too low to provide conclusive evidence of avoidance (indicated by wide range of Ivlev's electivity index CIs -1 to 0.67 ). The 
TABLE 4

Ivlev's Electivity Indices ( $\pm 95 \%$ CI) for Fish and Nudibranch Species Recorded at Hoga and Sampela

\begin{tabular}{|c|c|c|c|c|c|c|}
\hline & \multirow[b]{2}{*}{ Family } & \multirow[b]{2}{*}{ Species } & \multicolumn{2}{|r|}{ Sampela } & \multicolumn{2}{|r|}{ Hoga } \\
\hline & & & $n$ & Ivlev Index & $n$ & Ivlev Index \\
\hline \multirow[t]{16}{*}{ Fish } & Acanthuridae & Acantburus pyroferus & 3 & $0.39(0.13,0.63)$ & 3 & $0.85(0.70,0.96)$ \\
\hline & Acanthuridae & Ctenochaetus binotatus & 3 & $0.15(-0.22,0.47)$ & 3 & $0.91(0.83,0.98)$ \\
\hline & Acanthuridae & Ctenochaetus striatus & 3 & $-0.78(-1.00,-0.31)$ & & \\
\hline & Blenniidae & Ecsenius pictus & & & 3 & $0.96(0.92,0.99)$ \\
\hline & Chaetodontidae & Chaetodon kleinii & 3 & $0.87(0.80,0.93)$ & 3 & $0.97(0.95,0.99)$ \\
\hline & Chaetodontidae & Chaetodon vagabundus & & & 3 & $0.27(-1.00,0.87)$ \\
\hline & Chaetodontidae & Forcipiger flavissimus & 3 & $-0.15(-1.00,0.67)$ & 3 & $0.84(0.65,0.96)$ \\
\hline & Labridae & Halichoeres prosopeion & 3 & $-0.08(-1.00,0.74)$ & 3 & $0.13(-1.00,0.94)$ \\
\hline & Nemipteridae & Scolopsis bilineata & 3 & $-0.12(-1.00,0.71)$ & 3 & $0.07(-1.00,0.93)$ \\
\hline & Pomacanthidae & Centropyge bicolor & 3 & $-0.56(-1.00,-0.06)$ & & \\
\hline & Pomacanthidae & Centropyge nox & & & 3 & $0.58(-1.00,0.93)$ \\
\hline & Pomacanthidae & Centropyge tibicen & 3 & $-0.1(-1.00,0.43)$ & 3 & -1 \\
\hline & Pomacanthidae & Pomacanthus sexstriatus & & & 3 & $0.91(0.78,0.98)$ \\
\hline & Pomacanthidae & Pygoplites diacanthus & 3 & $0.82(0.66,0.91)$ & & \\
\hline & Tetraodontidae & Arotbron nigropunctatus & 3 & $0.73(0.48,0.87)$ & & \\
\hline & Zanclidae & Zanclus cornutus & 3 & $0.87(0.81,0.92)$ & 3 & -1 \\
\hline \multirow[t]{5}{*}{ Nudibranchs } & Chromodorididae & $\begin{array}{l}\text { Chromodoris sp. } \\
\quad \text { (cf. C. dianae })\end{array}$ & & & 7 & $0.17(-1.00,0.91)$ \\
\hline & Chromodorididae & Chromodoris lochi & & & 15 & $0.46(-1.00,0.88)$ \\
\hline & Phyllidiidae & Phyllidia elegans & 6 & $0.13(-1.00,0.87)$ & & \\
\hline & Phyllidiidae & Pbyllidiella pustulosa & 12 & $0.87(0.76,0.93)$ & & $0.32(-1.00,0.96)$ \\
\hline & Phyllidiidae & Phyllidia varicosa & 4 & $0.88(0.72,0.94)$ & & \\
\hline
\end{tabular}

angelfish that were observed taking bites of sponge included Pygoplites diacantbus, Pomacanthus sexstriatus, and three species of pygmy angelfish. Pomacanthus sexstriatus is a large angelfish that fed on a variety of sponges. The three individuals of $P$. sexstriatus that were observed only took a mean of $2(\mathrm{SD}=3)$ bites on

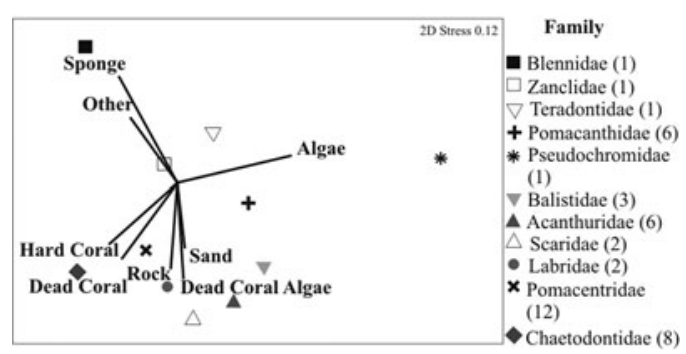

Figure 2. Unconstrained nonmetric MDS plot illustrating differences in the food items fed on by different fish families. sponge but sponges accounted for a large proportion of the total bites taken by this species (29\% on sponges) and showed a strong preference for sponges $(E=0.91)$. The three Centropyge spp. of pygmy angelfish-bicolor, nox, and tibicen - took fewer bites of sponge and fed on coralline algae, dead coral covered in algae, and other algae to a greater extent. Sponges accounted for a large proportion of the bites taken by the blenny Ecsenius pictus, the pufferfish Arotbron nigropunctactus and the Moorish idol Z. cornutus (Figure 2). Zanclus cornutus only fed on sponges at Sampela where two of the individuals were observed taking bites of $X$. testudinaria.

\section{Nudibranchia Surveys}

In total 132 individual nudibranchs were recorded belonging to 26 species in nine different genera. Nudibranchia densities varied 

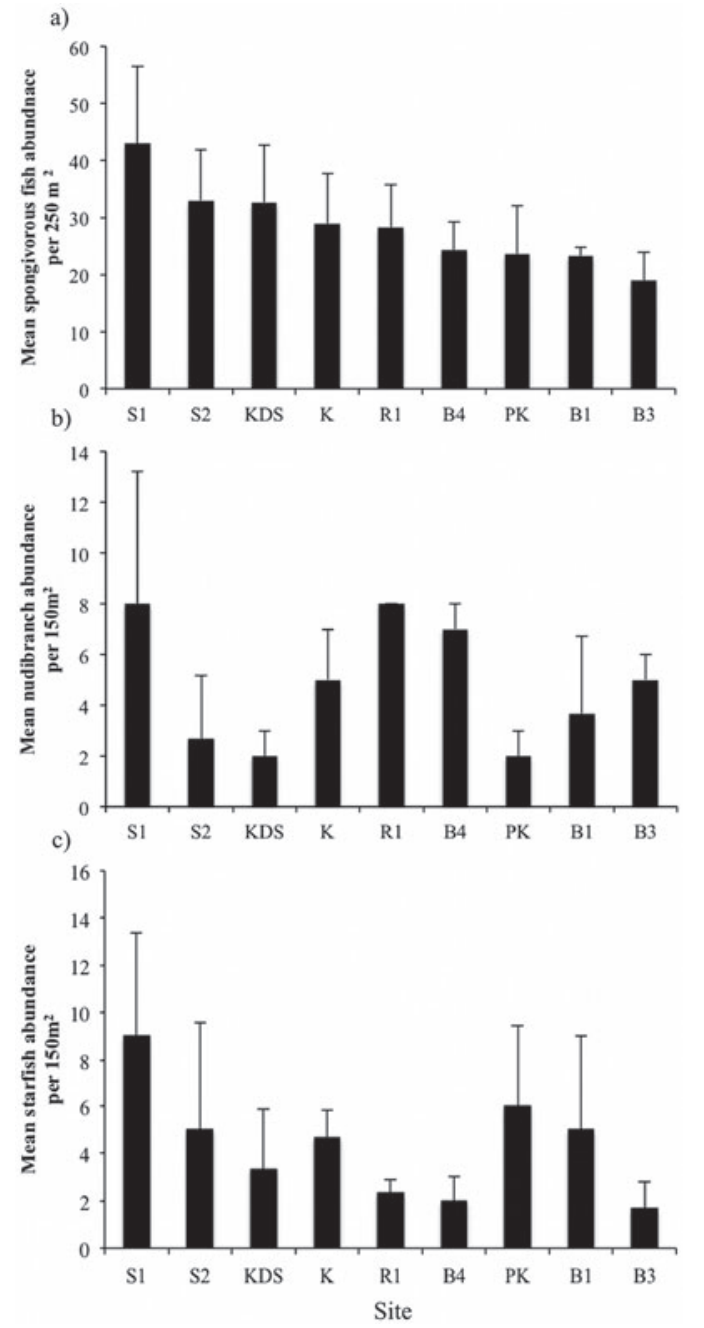

Figure 3. (a) Mean spongivorous fish densities at the study sites. (b) Mean nudibranch densities at the study sites. (c) Starfish densities at the study sites. Error bars represent +1 SD. $\mathrm{B}=$ Buoy, $\mathrm{K}=$ Kaledupa, $\mathrm{KDS}=$ Kaledupa Double Spur, PK= Pak Kasim's, R=Ridge, $\mathrm{S}=$ Sampela.

significantly across all sites surveyed (PERMANOVA, $\mathrm{df}=8$, pseudo- $F=2.671, P=.019$ ) (Figure 3). Mean abundance was highest at Sampela 1 and Ridge 1, but there was high variability between transects at Sampela indicating that nudibranch abundance was patchy at this site. The lowest mean abundances were recorded at Pak Kasim's and Kaledupa Double Spur (Figure 3).

At Sampela, the nudibranchs most strongly associated with sponges were Phyllidia varicosa $(E=0.88)$ and Phyllidiella pustulosa $(E=0.87)$ (Table 4). On Hoga reef slopes, three species of nudibranch, Phyllidiella pustulosa, Chromodoris cf. dianae, and Chromodoris lochi appear to be positively associated with sponges, but the large CI ranges on Ivlev's electivity index estimates for these species indicate that more data is needed for these species.

\section{Asteroidea Surveys}

During invertebrate surveys, 117 starfish were recorded from 10 different species. The three most abundant starfish species were Linckia laevigata $(n=62)$, Choriaster granulata $(n=20)$, and Celerina beffernani $(n=19)$. The remaining species each accounted for $<5 \%$ of the total number observed. Starfish abundance was highest at Sampela 1 and lowest at Buoy 3 (Figure 3). Of all the starfish recorded, only two individuals were found on sponges. The first was 1 of the 19 Celerina heffernani specimens recorded and the second was the only Gomophia egeria that was observed.

\section{Caging Effects on Sponge Abundance}

Mean sponge abundance per quadrat was higher at the Hoga site than at Sampela at the start of the experiment with a mean sponge abundance of $15(\mathrm{SD}=14)$ sponges $/ \mathrm{m}^{2} \mathrm{com}-$ pared with $7(\mathrm{SD}=4)$ sponges $/ \mathrm{m}^{2}$ at Sampela. Over the course of the experiment, sponge abundance increased in all treatments at both sites (see Figure 4). The biggest increase in mean sponge abundance occurred in the control plots at Hoga and in the partial plots at Sampela. No significant differences were detected between treatments at Hoga or Sampela.

\section{Power Analyses}

Power to detect differences between caged and noncaged control treatments differed at Hoga and Sampela (Figure 5). At Sampela, the 
a)
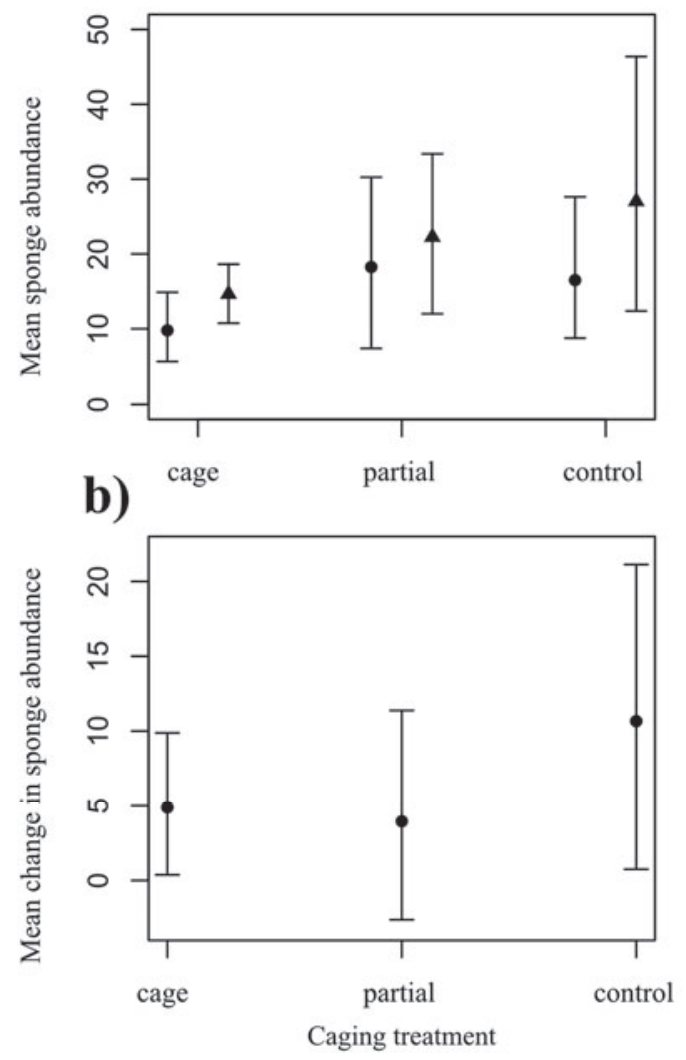

Sampela
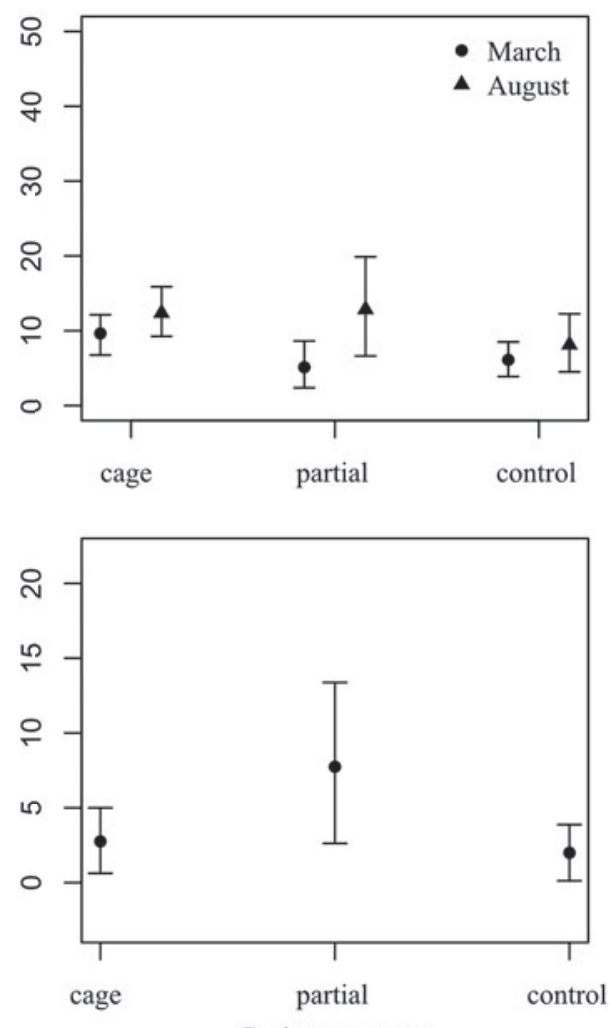

Caging treatment

Figure 4. (a) Mean sponge abundance ( $\pm 95 \%$ CI) plotted for caging treatments in March and August at Hoga and Sampela. (b) Mean change in sponge abundance $( \pm 95 \% \mathrm{CI})$ in the caging treatments at Hoga and Sampela.

experiment would have had high power (80\%) to detect effect sizes representing an approximate $70 \%$ increase in mean sponge abundance in caged treatments. For Hoga, the experiment would have only had sufficiently high power to detect larger effects representing a $100 \%$ increase in sponge abundance within caged treatments (Figure 5). At both sites, power to detect smaller effects was low.

\section{Caging Effects on Sponge Assemblages}

Multivariate PERMANOVA analyses revealed that sponge assemblages only differed among sites $(\mathrm{df}=1$, pseudo- $F=8.101$, $P=.0001$ ), with no significant differences among experimental treatments, time peri- ods, or as a result of interactions among these terms. This was further supported by visualization of the data using an unconstrained nonmetric MDS plot (not shown).

\section{DISCUSSION}

Sponges are diverse and abundant in the Wakatobi region (Bell and Smith 2004) and therefore represent a potential food resource for many species. We aimed to identify spongivorous vertebrates and invertebrates in this region and to provide a preliminary assessment of their effect on the abundance of noncryptic reef sponges. It is important to note that our identification of spongivores could be an underestimate as any species that only fed 


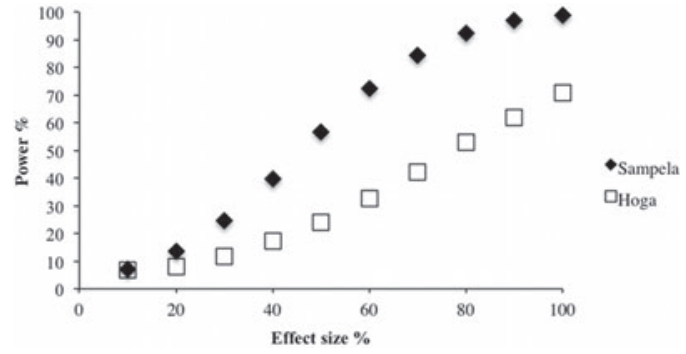

Figure 5. Power for rejecting the null hypothesis of no caging effect (5\% significance) as a function of hypothetical increases in sponge abundance in caged treatments.

on palatable sponges in cryptic habitats would not be included. The main vertebrate spongivores on reef slopes in the WMNP were fish (only one turtle was observed during the study and it was not feeding), while nudibranchs were the main invertebrate spongivores. Nine fish species were identified to be selectively feeding on sponges (of 45 observed directly), while 5 species of nudibranch were positively associated with sponges. Furthermore, spongivorous fish abundance was highest at high sediment, low coral cover sites.

Of the fish that were observed feeding on sponges, some were in families well known to feed on sponges including Pomacanthidae and Zanclidae. Two species of angelfish Pygoplites diacanthus and Pomacanthus sexstriatus fed preferentially on sponges $(E>0.80)$. This is consistent with studies of fish feeding behavior and gut content analyses from the Caribbean that show sponges are a major part of the diets of a number of angelfish species (Randall and Hartmann 1968, Hourigan et al. 1989, Wulff 1994, Dunlap and Pawlik 1996). Of the four species of pygmy angelfish observed, only Centropyge nox fed more on sponge than would be expected given the availability of sponge at Buoy $3(E>0.50)$. Previous work suggests that there is considerable variation between the diets of species within this genus with some species being strictly herbivorous and others consuming benthic invertebrates. Our results highlight the variability within this genus and indicate that sponges do not constitute a large proportion of the diets of the other three Centropyge spp. observed-bicolor, bispinosa, and tibicen.
Zanclus cornutus, commonly known as the Moorish idol and the only member of the family Zanclidae, has been reported to feed on sponges in a number of areas throughout the Pacific (Hobson 1974, Sano et al. 1984). In the present study, Moorish idols showed a strong preference for sponges $(E>0.80)$ but interestingly only at Sampela, which is considered a degraded site (high sediment and low coral cover) (see Table 1), where they particularly fed on the giant barrel sponge $X$. testudinaria. This species exhibits plasticity in its feeding behavior as at the higher coral cover site (Buoy 3), Z. cornutus was observed to feed on coralline algae (60\% of all bites), hard coral, ascidians, and algae. A possible explanation for this difference is that Moorish idols have a preference for particular sponge species, such as X. testudinaria, which are more common at Sampela than at Buoy 3. Alternatively, it is possible that at Buoy 3, Moorish idols are able to feed on a wider range of food items, whereas at Sampela, hard coral and coralline algae cover are much lower (see Table 1) and therefore their diets are predominantly sponge-based due to the lack of alternative food sources. This could highlight the potential for sponges to become preferred food sources for species when other food sources decline or become unavailable.

This study highlights geographic differences in the feeding behavior of certain families and species. Although the butterflyfish Chaetodon kleinii has been previously described as a zooplanktivore (Hobson 1974), our results suggest that in the WMNP this species shows a strong preference for sponges $(E>0.90)$ and feeds to a lesser extent on hard coral and algae. This species has also been reported to feed on sponges on the Great Barrier Reef (Nagelkerken et al. 2009). A difference between the spongivorous fish of the WNMP and those reported from the Caribbean was the lack of spongivory by parrotfish. This contrasts with results from the Florida Keys where Dunlap and Pawlik (1998) found that Sparisoma aurofrenatum and particularly schools of juvenile Scarus croicensis or Scarus taeniopterus fed on Xestospongia muta. The two species of parrotfish that we observed, Scarus niger and Chlorurus bleekeri, fed mainly on hard coral, algae, and coralline algae. 
An unexpected finding of this study was that two species of surgeonfish, Ctenochaetus binotatus and Acanthurus pyroferus appeared to feed on sponges. Rather than actively cropping algae, surgeonfish in the Ctenochaetus genus are thought to use their sectorial mouths and soft comb-like teeth to scrape detritus and sediment from the substrate (Randall 1955, 1980). Consequently, it seems likely that $C$. binotatus was feeding on detritus and mucous on the surface of the sponge. However, the fact that this species was observed to interact with sponges more than expected given the percentage cover of sponge in the environment $(E>0.80)$ suggests that this species derives a particular benefit from scraping the surfaces of sponges. Acanthurus pyroferus also appeared to feed predominantly on sponges $(E>0.70)$, which contrasts with the results of earlier gut content analyses that indicated that this species feeds on algae and detritus (Eagle and Jones 2004).

Twenty-one of the 26 species of nudibranchs recorded during the invertebrate surveys were in the sponge feeding families Chromodoridae and Phyllidiidae, including the three most abundant species-Phyllidiella pustulosa, Chromodoris lochi, and Phyllidia elegans. The extent to which predation by nudibranchs regulates sponge abundance is currently unclear. A number of studies in tropical, temperate, and polar systems suggest that nudibranchs typically only partially consume their sponge prey (Dayton et al. 1974, Yasman 2003, Gemballa and Schermutzki 2004). This evidence combined with the fact that many sponges show rapid regeneration rates suggests that in many cases nudibranch predation is unlikely to have a major impact on sponge populations. A study in Alaska found that a large recruitment event of a dorid nudibranch, Archidoris montereyensis, resulted in the complete disappearance of the sponge, Halichondria panicea, in an area where it had previously occupied up to $40 \%$ of the substratum. However, this appears to be a rare event, but events such as this may be important in controlling sponge abundance over longer time-scales than this study was able to capture. In the present study, the most abun- dant nudibranch Pbyllidiella pustulosa $(n=40)$ only occurred at densities of $2.11 \pm 1.59$ per $150 \mathrm{~m}^{2}$ so it seems unlikely that at such low densities nudibranchs could exert a strong impact on overall sponge abundance. However, some nudibranch species have evolved trophic specializations toward particular sponge species (e.g., Gemballa and Schermutzki 2004) so it is possible that nudibranch predation plays a greater role in determining the abundance of these preferred prey species. In addition, our surveys were restricted to daylight hours so our results would not include any species that were predominantly active at night.

Despite observing spongivory by a number of fish species, excluding fish predators did not appear to have a significant effect on the abundance or assemblage composition of sponges in our study plots. Although the experiment had low power to detect weak effects, our analysis revealed that if fish predation is having an effect on the sponges contained within our experimental plots, the effect is likely to be small. One possible explanation for this is that the sponges in our plots were chemically defended against fish predators. In the Caribbean, many sponges that occur in locations where they are exposed to predation have evolved chemical defenses against predators and the proportion of chemically defended sponges is highest on the reefs with greater spongivore abundance (Loh and Pawlik 2014). Furthermore, translocation experiments have shown that some palatable sponges are restricted to nonreef habitats (Dunlap and Pawlik 1996, 1998, Pawlik 1998, Wulff 2000, Hill and Hill 2002, Wulff 2005). Further research on the chemical ecology of the sponges in the WMNP is necessary to determine whether the species that occur exposed to predators on vertical reef walls have evolved chemical defenses to avoid being consumed. It is also important to note that our caging experiment could only detect total loss of the sponge (complete mortality) rather than partial predation (as we counted the number of patches), which means we may have underestimated biomass of sponge consumed as partial predation may be common (Wulff 2006a). 
The increase in sponge abundance in all the experimental plots over time indicates that sponge assemblages in the WMNP are not static and changes can occur over relatively short periods. In the Caribbean, a long-term decline (over 14 years) in abundance and diversity of a reef sponge community was linked to disease in Panama (Wulff 2006b) and increases in abundance of $X$. muta over a $6-\mathrm{yr}$ period were related to recruitment pulses in the Florida Keys (McMurray et al. 2010). A study of a subtropical rocky coast sponge assemblage in Mexico revealed short-term fluctuations were correlated with seasonal changes in local wind patterns and sediment deposition, nested within large-scale annual patterns related to the Southern Oscillation and Multivariate El Niño Southern Oscillation indices (Carballo et al. 2008). Longer-term monitoring of the sponge assemblages at Hoga and Sampela are necessary in order to determine the cause of the observed increase in sponge abundance and whether these increases are part of a long-term trend or shortterm seasonal fluctuations.

\section{CONCLUSIONS}

We found evidence that fish and nudibranchs are the most important sponge predators in the WMNP. Although the overall number of spongivorous fish species was relatively low, supporting the conclusions drawn from previous gut-contents studies in the Pacific, based on their abundance and feeding observations, the fish with the greatest potential to influence sponge assemblages in the WMNP were Z. cornutus, Chaetodon kleinii, Pygoplites diacanthus, and Pomacanthus sexstriatus. These results represent a first step toward understanding the role of fish predation in controlling sponge diversity and abundance in the WMNP.

\section{ACKNOWLEDGMENTS}

The authors wish to thank Operation Wallacea and the staff of Hoga Island Marine Research Station and Victoria University of Wellington for their support and assistance in conducting this research. We also thank Jason Williams for producing the site map.

\section{Literature Cited}

Allen, G., and M. Adrim. 2003. Coral reef fishes of Indonesia. Zool. Stud. 42 (1): 1-72.

Allen, G. R. 2008. Conservation hotspots of biodiversity and endemism for Indo-Pacific coral reef fishes. Aquatic Conserv. Mar. Freshw. Ecosyst. 18 (5): 541-556.

Anderson, M. J., R. N. Gorley, and K. R. Clarke. 2008. PERMANOVA+ for PRIMER: Guide to software and statistical methods. PRIMER-E: Plymouth, United Kingdom.

Bell, J. J. 2008. The functional roles of marine sponges. Estuar. Coast. Shelf Sci. 79 (3): 341-353.

Bell, J. J., S. K. Davy, T. Jones, M. W. Taylor, and N. S. Webster. 2013. Could some coral reefs become sponge reefs as our climate changes? Glob. Change Biol. 19:2613-2624.

Bell, J. J., and D. J. Smith. 2004. Ecology of sponge assemblages (Porifera) in the Wakatobi region, south-east Sulawesi, Indonesia: richness and abundance. J. Mar. Biol. Assoc. U. K. 84 (3): 581-591.

Bruno, J. F., and E. R. Selig. 2007. Regional decline of coral cover in the Indo-Pacific: Timing, extent, and subregional comparisons. PLoS ONE 2:e711. doi:10.1371/ journal.pone.0000711.

Burke, L., K. Reytar, M. Spalding, and A. Perry. 2011. Reefs at risk revisited. World Resources Institute, Washington, D.C.

Carballo, J. L., C. Vega, J. A. Cruz-Barraza, B. Yáñez, H. Nava, E. Avila, and M. Wilson. 2008. Short and long term patterns of sponge diversity on a rocky tropical coast: Evidence of large-scale structuring factors. Mar. Ecol. 29 (2): 216-236.

Chase, J. M., P. A. Abrams, J. P. Grover, S. Diehl, P. Chesson, R. D. Holt, S. A. Richards, R. M. Nisbet, and T. J. Case. 2002. The interaction between predation and competition: A review and synthesis. Ecol. Lett. 5 (2): 302-315.

Cheal, A. J., M. A. MacNeil, E. Cripps, M. J. Emslie, M. Jonker, B. Schaffelke, and H. 
Sweatman. 2010. Coral-macroalgal phase shifts or reef resilience: Links with diversity and functional roles of herbivorous fishes on the Great Barrier Reef. Coral Reefs 29:1005-1015.

Clifton J., and R. K. F. Unsworth. 2010. Introduction to the Wakatobi National Park. Pages 1-9 in J. Clifton, R. F. K. Unsworth, and D. J. Smith, eds. Marine conservation and research in the Coral Triangle: The Wakatobi National Park. Nova Publishers, New York.

Cohen, J. 1977. Statistical power analysis for the behavioral sciences. Academic Press, New York.

Cullen-Unsworth, L. C., J. Pretty, and D. J. Smith. 2011. Developing communityderived indicators of the economic impact of conservation management in the Coral Triangle. Ocean Coast. Manag. 54 (6): 446-454.

Dayton, P., G. Robilliard, and R. Paine. 1974. Biological accommodation in the benthic community at McMurdo Sound, Antarctica. Ecol. Monogr. 44:105-128.

Dunlap, M., and J. R. Pawlik. 1996. Videomonitored predation by Caribbean reef fishes on an array of mangrove and reef sponges. Mar. Biol. 126:117-123.

. 1998. Spongivory by parrotfish in Florida mangrove and reef habitats. Mar. Ecol. 19 (4): 325-337.

Eagle, J. V., and G. P. Jones. 2004. Mimicry in coral reef fishes: Ecological and behavioural responses of a mimic to its model. J. Zool. 264 (1): 33-43.

Edinger, E., J. Jamaluddin, G. V. Limmon, W. Widjatmoko, and M. J. Risk. 1998. Reef degradation and coral biodiversity in Indonesia: Effects of land-based pollution, destructive fishing practices and changes over time. Mar. Pollut. Bull. 36 (8): 617-630.

Exton, D. 2010. Nearshore fisheries of the Wakatobi. Pages 193-207 in J. Clifton, R. K. F. Unsworth, and D. J. Smith, eds. Marine research and conservation in the Coral Triangle: The Wakatobi National Park. Nova Science Publishers, New York.

Faul, F., E. Erdfelder, A. G. Lang, and A. Buchner. 2007. G*Power 3: A flexible sta- tistical power analysis program for the social, behavioral, and biomedical sciences. Behav. Res. Meth. 39:175-191.

Gemballa, S., and F. Schermutzki. 2004. Cytotoxic haplosclerid sponges preferred: A field study on the diet of the dotted sea slug Peltodoris atromaculata (Doridoidea: Nudibranchia). Mar. Biol. 144 (6): 12131222.

Hiatt R. W., and D. W. Strasburg. 1960. Ecological relationships of the fish fauna on coral reefs of the Marshall Islands. Ecol. Monogr. 30 (1): 65-127.

Hill, M. S. 1998. Spongivory on Caribbean reefs releases corals from competition with sponges. Oecologia 117 (1): 143-150.

Hill, M. S., and A. L. Hill. 2002. Morphological plasticity in the tropical sponge $A n$ thosigmella varians: Responses to predators and wave energy. Biol. Bull. 202 (1): 86-95.

Hobson, E. S. 1974. Feeding relationships of teleostean fishes on coral reefs in Kona, Hawaii. Fish. Bull. 72 (4): 915-1031.

Holt, R. D. 1984. Spatial heterogeneity, indirect interactions, and the coexistence of prey species. Am. Nat. 124 (3): 377-406.

Hourigan, T., F. Stanton, and P. Motta. 1989. The feeding ecology of three species of Caribbean angelfishes (family Pomacanthidae). Environ. Biol. Fishes 24 (2): 105-116.

Hughes, T. P., M. J. Rodrigues, D. R. Bellwood, D. Ceccarelli, O. Hoegh-Guldberg, L. McCook, N. Moltschaniwskyj, M. S. Pratchett, R. S. Steneck, and B. Willis. 2007. Phase shifts, herbivory, and the resilience of coral reefs to climate change. Curr. Biol. 17:360-365.

Ivlev, V. S. 1961. Experimental ecology of the feeding of fishes. Yale University Press, New Haven, Connecticut.

Kohler, K. E., and S. M. Gill. 2006. Coral Point Count with Excel extensions (CPCe): A Visual Basic program for the determination of coral and substrate coverage using random point count methodology. Comput. Geosci. 32 (9): 1259-1269.

Lefèvre, C. D., and D. R. Bellwood. 2011. Temporal variation in coral reef ecosystem processes: Herbivory of macroalgae by fishes. Mar. Ecol. Prog. Ser. 422:239-251. 
León, Y., and K. Bjorndal. 2002. Selective feeding in the hawksbill turtle an important predator in coral reef ecosystems. Mar. Ecol. Prog. Ser. 245:249-258.

Lesser, M. P., and M. Slattery. 2013. Ecology of Caribbean sponges: Are top-down or bottom-up processes more important? PLoS ONE 8 (11): e79799. doi:10.1371/ journal.pone.0079799.

Levin, S. A. 1992. The problem of pattern and scale in ecology: The Robert H. MacArthur award lecture. Ecology 73 (6): 19431967.

Loh, T., and J. R. Pawlik. 2014. Chemical defenses and resource trade-offs structure sponge communities on Caribbean coral reefs. Proc. Natl. Acad. Sci. U.S.A. 111 (110): 4151-4156.

McMellor, S., and D. J. Smith. 2010. Coral reefs of the Wakatobi: Abundance and biodiversity. Pages 11-26 in J. Clifton, R. K. F. Unsworth, and D. J. Smith, eds. Marine research and conservation in the Coral Triangle: The Wakatobi National Park. Nova Science Publishers, New York.

McMurray, S. E., T. P. Henkel, and J. R. Pawlik. 2010. Demographics of increasing populations of the giant barrel sponge Xestospongia muta in the Florida Keys. Ecology 91:560-570.

Meylan, A. 1988. Spongivory in Hawksbill turtles: A diet of glass. Science 239 (4838): 393-395.

Meylan, A. B., and M. Donnelly. 1999. Status justification for listing the Hawksbill Turtle (Eretmochelys imbricata) as critically endangered on the 1996 IUCN Red List of Threatened Animals. Chelonian Conserv. Biol. 3 (2): 200-224.

Nagelkerken, I., G. van der Velde, S. L. J. Wartenbergh, M. M. Nugues, and M. S. Pratchett. 2009. Cryptic dietary components reduce dietary overlap among sympatric butterflyfishes (Chaetodontidae). J. Fish Biol. 75 (6): 1123-1143.

Padilla Verdin, C. J., J. L. Carballo, and M. L. Camacho. 2010. A qualitative assessment of sponge-feeding organisms from the Mexican Pacific Coast. Open Mar. Biol. J. 4:3946.
Paine, R. T. 1969. A note on trophic complexity and community stability. Am. Nat. 103 (929): 91-93.

Pawlik, J. R. 1998. Coral reef sponges: Do predatory fishes affect their distribution? Limnol. Oceanogr. 43 (6): 1396-1399.

Pawlik, J. R., T. L. Loh, S. E. McMurray, and C. M. Finelli. 2013. Sponge communities on Caribbean coral reefs are structured by factors that are top-down, not bottom-up. PLoS ONE 8 (5): e62573. doi:10.1371/ journal.pone.0062573.

Pawlik, J. R., S. E. McMurray, and T. P. Henkel. 2007. Abiotic factors control sponge ecology in Florida mangroves. Mar. Ecol. Prog. Ser. 339:93-98.

Pet-Soede, C., H. S. J. Cesar, and J. S. Pet. 1999. An economic analysis of blast fishing on Indonesian coral reefs. Environ. Conserv. 2:83-93.

Powell, A., D. J. Smith, L. J. Hepburn, T. Jones, J. Berman, J. Jompa, and J. J. Bell. 2014. Reduced diversity and high sponge abundance on a sedimented Indo-Pacific reef system: Implications for future changes in environmental quality. PLoS ONE 9 (1): e75253. doi:10.1371/journal. pone. 0085253 .

R Core Team. 2013. R: A language and environment for statistical computing. R Foundation for Statistical Computing, Vienna, Austria. Accessed 1 June 2014. http:// www.R-project.org/.

Randall, J. 1955. Fishes of the Gilbert Islands. Atoll Res. Bull. 47:1-243.

- 1980. A survey of ciguatera at Enewetak and Bikini, Marshall Islands, with notes on the systematics and food habits of ciguatoxic fishes. Fish. Bull. 78 (2): 201-249.

Randall, J., and W. Hartman. 1968. Spongefeeding fishes of the West Indies. Mar. Biol. 1 (3): 216-225.

Salinas-de-León, P., A. Costales-Carrera, S. Zeljkovic, D. J. Smith, and J. J. Bell. 2011. Scleractinian settlement patterns to natural cleared reef substrata and artificial settlement panels on an Indonesian coral reef. Estuar. Coast. Shelf Sci. 93 (1): 80-85.

Sano, M. 1989. Feeding habits of Japanese butterflyfishes (Chaetodontidae). Environ. Biol. Fishes 25 (1-3): 195-203. 
Sano, M., M. Shimizu, and Y. Nose. 1984. Food habits of teleostean reef fishes in Okinawa Island, southern Japan. University of Tokyo Bull. 25. University of Tokyo Press, Tokyo, Japan.

Shapiro, S. S., and M. B. Wilk. 1965. An analysis of variance test for normality (complete samples). Biometrika 52:591-611.

Sih, A., P. Crowley, M. McPeek, J. Petranka, and K. Strohmeier. 1985. Predation, competition, and prey communities: A review of field experiments. Annu. Rev. Ecol. Syst. 16 (1): 269-311.

Thomas, L. 1997. Retrospective power analysis. Conserv. Biol. 11 (1): 276-280.

Todd, P., X. Ong, and L. Chou. 2010. Impacts of pollution on marine life in Southeast Asia. Biodivers. Conserv. 19 (4): 1063-1082.

Van Soest, R. W. M. 1989. The Indonesian sponge fauna: A status report. Neth. J. Sea Res. 23 (2): 223-230.

Van Soest, R. W. M., N. Boury-Esnault, J. Vacelet, M. Dohrmann, D. Erpenbeck, N. J. De Voogd, N. Santodomingo, B. Vanhoorne, M. Kelly, and J. N. A. Hooper. 2012. Global diversity of sponges (Porifera). PLoS ONE 7 (4): e35105. doi:10.1371/ journal.pone. 0035105 .

Wulff, J. L. 1994. Sponge feeding by Caribbean angelfishes, trunkfishes, and filefishes. Pages 265-271 in R. W. M. van
Soest, T. M. G. van Kempen, and J. C. Braekman, eds. Sponges in time and space. Balkema, Rotterdam. 1997a. Parrotfish predation on cryptic sponges of Caribbean coral reefs. Mar. Biol. 129 (1): 41-52. 1997b. Causes and consequences of differences in sponge diversity and abundance between the Caribbean and eastern Pacific of Panama. Proc. 8th Int. Coral Reef Sym. 2:1377-1382.

- 2000. Sponge predators may determine differences in sponge fauna between two sets of mangrove cays, Belize barrier reef. Atoll Res. Bull. 477 (477): 251-263.

- 2005. Trade-offs in resistance to competitors and predators, and their effects on the diversity of tropical marine sponges. J. Anim. Ecol. 74 (2): 313-321.

. 2006a. Ecological interactions of marine sponges. Can. J. Zool. 84:146-166.

- 2006b. Rapid diversity and abundance decline in a Caribbean coral reef sponge community. Biol. Cons. 127:167-176.

Yasman. 2003. Observation on the feeding of nudibranch Phyllidia varicosa Lamarck, 1801 on the sponge Axinyssa cf. aculeata Wilson, 1925 in coral reefs of Pramuka Island, Thousands Islands National Park, Indonesia. Makara, Sains 7 (1): 15-21. 